\title{
Ultraviolet A Radiation, Reactive Oxygen Species and NF-kappa B
}

\section{Li Xiao*}

Department of Pharmacology, The Nippon Dental University School of Life Dentistry at Tokyo, 1-9-20 Fujimi, Chiyoda-ku, Tokyo 102-8159, Japan

Over the past decades, the harmful biological effects of solar Ultraviolet (UV) irradiation became serious issue because of the disruption of the ozone layer. UV radiation has a strong potential for the generation of Reactive Oxygen Species (ROS) and depletion of endogenous antioxidant systems, in the extracellular space and intracellular sphere. These highly reactive oxygen intermediates can readily react with various biological macromolecules such as DNA, proteins and lipids to cause mutations, peroxidation of membrane lipids, and protein destruction. These lesions in turn lead to various degenerative processes such as skin aging, pigmentation and carcinogenesis [1-4]. UVA (320-400 nm) and UVB (290-320 nm) are the major components of solar UV irradiation. UVA makes a more intense impact on oxidative stress in the skin than UVB through generation of reactive oxygen and nitrogen species [5-7]. Antioxidants showed limited protective effects for UVA-injures. However the strategies for UVA-protection are still needed to be discovered in some parts.

UVA damages the skin because its absorption leads to primary and secondary photochemical reactions: (i) initially to inflammation responses (acute photodamage) and lately to manifestations of photoageing, and sometimes skin cancer. (ii) Free radicals and reactive oxygen species generated by UVA act as a secondary reactor can alter elastin and collagen fibers, leading to premature wrinkling. DNA can be damaged by ROS in addition to directly by UVA, and both can potentially lead to carcinogenesis. Numerous molecules, such as Nuclear Transcriptional Factor kappa B (NF-kappa B), p53 and Tumor Necrosis Factor (TNF) are involved in UVA-mediated biological processes [8-10]. Among them, NF-kappa B plays the most essential role in mediating the above-mentioned reactions and pathological consequences.

In resting cells, NF-kappa B resides in the cytoplasm in an inactive form bound to an inhibitory protein known as I-kappa B. Upon cellular activation by extracellular stimuli, such as oxidative stress induced signals, I-kappa B is phosphorylated and proteolytically degraded or processed by proteasomes and other proteases. This proteolytic process activates NF-kappa B, which then translocates into the nucleus. In nuclei, NF-kappa B can initiate or regulate early-response gene transcription by binding to decameric motifs, "GGGRNNYYCC (kappa B motif)", found in the promoter or enhancer regions of specific genes that regulate innate and adaptive immunity, inflammation, cell growth and cell survival $[8,11]$.

UVA in the physiological range of doses has been shown to induce the NF-kappa B DNA-binding activity in human skin cells. UVA- oxidant stress dependent activation of NF-kappa B appeared to be correlated with membrane damage [12]. During this pathological process, labile iron acts as a catalyst to exacerbate the generation of lipid secondary messengers in human skin fibroblasts membranes that are responsible for induction of NF-kappa B [13]. UVA-induced ROS formation rapidly releases labile irons, which mediate lipid peroxidation in cell membranes, and consequently increase the permeability of nuclear membrane. Evidences showed that this ironinduced lipid peroxidation in cell membranes is the main contributor to induction of NF-kappa B [14]. Therefore, to protect skin cells from UVA-injures, potential reagents should be able to scavenge cellular ROS, stabilize cellular membranes, and reduce NF-kappa B activation.
Fullerene and its derivatives have been characterized as powerful antioxidants [15]. In our previous study, Polyvinylpyrrolidone (PVP) -wrapped fullerene molecules (PVP-fullerene) could combine the proteins in cell membrane and prevent UVA-induced cell death through scavenging of intracellular ROS and reducing NF-kappa B activation. The result suggests that fullerenes may be developed as UVprotective agents in terms of the prevention of both skin aging and carcinogenesis [16].

\section{References}

1. Ulm R, Nagy F (2005) Signalling and gene regulation in response to ultraviole light. Curr Opin Plant Biol 8: 477-482.

2. Glanz K, Mayer JA (2005) Reducing ultraviolet radiation exposure to prevent skin cancer methodology and measurement. Am J Prev Med 29: 131-142.

3. Wakamatsu K, Nakanishi Y, Miyazaki N, Kolbe L, Ito S (2012) UVA-Induced Oxidative Degradation of Melanins: Fission of Indole Moiety in Eumelanin and Conversion to Benzothiazole Moiety in Pheomelanin. Pigment Cell Melanoma Res.

4. Marotta F, Kumari A, Yadav H, Polimeni A, Soresi V, et al. (2012) Biomarine extracts significantly protect from ultraviolet a-induced skin photoaging: an ex vivo study. Rejuvenation Res 15: 157-160.

5. Hseu YC, Chou CW, Senthil Kumar KJ, Fu KT, Wang HM, et al. (2012) Ellagic acid protects human keratinocyte (HaCaT) cells against UVA-induced oxidative stress and apoptosis through the upregulation of the $\mathrm{HO}-1$ and Nrf-2 antioxidant genes. Food Chem Toxicol 50: 1245-1255.

6. Swalwell H, Latimer J, Haywood RM, Birch-Machin MA (2012) Investigating the role of melanin in UVA/UVB- and hydrogen peroxide-induced cellular and mitochondrial ROS production and mitochondrial DNA damage in human melanoma cells. Free Radic Biol Med 52: 626-634

7. Aroun A, Zhong JL, Tyrrell RM, Pourzand C (2012) Iron, oxidative stress and the example of solar ultraviolet A radiation. Photochem Photobiol Sci 11: 118134.

8. Chen F, Castranova V, Shi X, Demers LM (1999) New insights into the role of nuclear factor-kappa $B$, a ubiquitous transcription factor in the initiation of diseases. Clin Chem 45: 7-17.

9. Svobodova AR, Galandakova A, Sianska J, Dolezal D, Lichnovska R, et al (2012) DNA damage after acute exposure of mice skin to physiological doses of UVB and UVA light. Arch Dermatol Res.

10. Pustisek N, Situm M (2011) UV-radiation, apoptosis and skin. Coll Antropol. 35 Suppl 2: 339-341.

11. Lee YK, Cha HJ, Hong M, Yoon Y, Lee H, et al. (2012) Role of NF-kB-p53 crosstalk in ultraviolet $A$-induced cell death and $\mathrm{G} 1$ arrest in human derma fibroblasts. Arch Dermatol Res 304: 73-79.

12. Vile GF, Tanew-llitschew A, Tyrrell RM (1995) Activation of NF-kappa B in human skin fibroblasts by the oxidative stress generated by UVA radiation. Photochem Photobiol 62: 463-468.

13. Bubici C, Papa S, Pham CG, Zazzeroni F, Franzoso G (2006) The NF-kappaBmediated control of ROS and JNK signaling. Histol Histopathol 21: 69-80.

Corresponding author: Li Xiao, Department of Pharmacology, The Nippon Dental University School of Life Dentistry at Tokyo, 1-9-20 Fujimi, Chiyoda-ku, Tokyo 102-8159, Japan, Tel: +81-3-3261-8772; Fax: +81-3-3264-8399; Email: xiaoli@tky.ndu.ac.jp

Received May 24, 2012; Accepted May 26, 2012; Published May 28, 2012

Citation: Xiao L (2012) Ultraviolet A Radiation, Reactive Oxygen Species and NFkappa B. Pharmaceut Reg Affairs 1:e107. doi:10.4172/2167-7689.1000e107

Copyright: (c) 2012 Xiao L. This is an open-access article distributed under the terms of the Creative Commons Attribution License, which permits unrestricted use, distribution, and reproduction in any medium, provided the original author and source are credited. 
Citation: Xiao L (2012) Ultraviolet A Radiation, Reactive Oxygen Species and NF-kappa B. Pharmaceut Reg Affairs 1:e107. doi:10.4172/21677689.1000 e107

14. Reelfs O, Tyrrell RM, Pourzand C (2004) Ultraviolet a radiation-induced immediate iron release is a key modulator of the activation of NF-kappaB in human skin fibroblasts. J Invest Dermatol 122: 1440-1447.

15. Krusic PJ, Wasserman E, Keizer PN, Morton JR, Preston KF (1991) Radical reaction of c60. Science 254: 1183-1185.
16. Xiao L, Aoshima H, Saitoh Y, Miwa N (2010) Fullerene-polyvinylpyrrolidone clathrate localizes in the cytoplasm to prevent Ultraviolet-A ray-induced DNAfragmentation and activation of the transcriptional factor NF-kappaB. J Cell Biochem 111: 955-966. 